\title{
Influencing Risk Factors in Construction Projects based on Time and Cost Overrun
}

\author{
Mukilan K, Rameshbabu C
}

\begin{abstract}
The development business is considered as a standout amongst the essential ventures everywhere globally since it is the foundation of the economy of our nation. It recognized that a large portion of the development extends in India presented to cost and time overwhelm that isn't attractive. In the development ventures, there are such a large number of exercises to be tended to like asset activation, coordination, time the board, and material administration to finish the task on time inside the allotted expense. It comprehended that each action should be observed and ought not to permit slack anytime. Be that as it may, in the present situation, a lot of studies should be done to streamline the exercises to complete a gainful task. In the development business, it is essential to have control of the cost execution of activities to guarantee the development cost is inside the spending limit. Cost and Time are among the real thought all through the undertaking course of stages and can see as the most significant variables of a venture and the main impetus of task achievement. In this investigation, chance variables related to development ventures have recognized, and furthermore, the seriousness of the risk has additionally dissected, and the solid outcomes have examined. This investigation comprises of three stages: The main period of the venture is gathering sorts of writing universally and discover the effectively recognized risk factors in this specific southern region. The second stage incorporates the survey plan for the recognized risk components and circulation of polls to neighbourhood contractual workers, advisors, proprietors and every single other partner of the task. The third period of the proposal concentrated on information examination and result talk. SPSS programming had been utilized for examining the information procured from the surveys. From this examination, it was fathomed that the peril earnestness changed in low and high spending improvement adventures. The thinking which ought to be grasped for managing the risks perceived for low and high spending errands has been discussed and reasoned in this examination.
\end{abstract}

Keywords : Overrun ,Risk,SPSS(Statistical Package for Social Science).

\section{INTRODUCTION}

The development business perceived as one of the centre areas considering the country economy [1]. The expense and time overwhelms have progressed toward becoming a piece of the development business in Indian country. As said by numerous specialists in this industry, among sixty percent of the tasks encountering plan postponements, and money invades because of a few reasons [3]. To keep up the current rate of development and increment, the advancement rate of

Revised Manuscript Received on December 05, 2019.

Mukilan K, Department of Civil Engineering, Kalasalingam Academy of Research and Education Email: mukicivil@gmail.com

Rameshbabu C, Department of Civil Engineering, Kalasalingam Academy of Research and Education Email: babussr@gmail.com the nation, the current dimension of the framework must be developed to world level later on. For this to occur, it is imperative to build the execution and the productivity of the development business [2]. Subsequently, a fitting system to define the issue by discovering the present difficulties and danger of the Construction business is significant. Employing appropriate administration methods to the current circumstance and tending to a couple of risk components can diminish the duration and cost delays by somewhere around fifty per cent from the present dimension [7]. The poll review is to distinguish and assess the basic components in charge of the calendar deferrals, and cost overwhelms in structure, and mechanical development extends in India[5].

\section{A. OBJECTIVES}

The principal targets of this investigation are:

- Identifying the seriousness of risk factors in an alternate kind of development ventures.

- Analyses the risk factor and seriousness recognized risk factor as indicated by the viewpoints of contractual workers and clients

- We are giving down to earth proposals and suggestions indicating overhauling the risk the boarding procedure in development and improve the execution of contracting organizations in this field.

- To distinguish the elements affecting time and cost invades in development ventures and to assess their relative significance.

- To detail proposals for improving time and cost execution

\section{B. SCOPE OF THE WORK}

The extent of the task is to distinguish the risk factors affecting duration and cost invades in development ventures and to succession the risk seriousness in the different high and low spending development activities and offer proposals to maintain a strategic distance from time and cost overwhelm to assess their relative significance.

\section{NEED}

Development ventures include incredible arrangement of duration and capital, so powerful development venture risk examination abilities are needed, if the activities are to be finished inside the setup course of events to meet money disposal and quality necessities. Risk is inalienable wherever particularly in development ventures. The exercises that are available in the development enterprises could result in fatal wounds, money related calamities, disturbance and deferred task, and so forth. There are numerous purposes behind investigating risk, yet the fundamental reason is that it can give critical

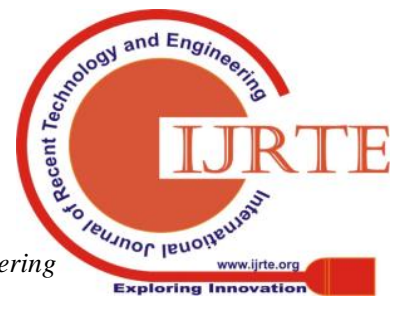


advantages extreme in abundance of the cost performing it.

\section{LITERATURE STUDY}

Cost attacks an essential issue in various Indian advancement adventures. The productive execution of advancement undertakings and keeping them inside supported date-book and cost is noteworthy for practical time execution and cost execution. This examination work finished on considering critical components causing Time overpowers and Cost attacks in Indian advancement adventures.[19] A significant study for the examination was made subject to segments for duration assaults, and factors for cost overwhelms apparent from make audit. These variables gathered into 12 orders for time assaults and eight groupings for cost overwhelms and dispersed to Contractors, Consultants, and clients of Indian Development Industry. The information from the study broke down quantifiable. Relative basic summary philosophy was utilized to develop out the most imperative variables influencing Time and Cost overwhelms. The outcome achieved from the examination uncovered that the veritable reason behind time overwhelms is material market rate, contract adjustment, and surprising state of huge worth fundamental and the real clarification behind cost assaults high transportation cost, change in material detail and expanding of materials cost. The examination revelations underline the basic factors, and a couple of suggestions are given to manage time and cost overrun in Indian Development Industry[19]

Building adventures in various countries have been continuously seeing the prerequisite for progressively gainful and helpful satisfaction of undertakings. As often as possible, different unanticipated issues and transforms from an exceptional arrangement rises a mid the improvement organize, advancing expense and time overpowers. Along these lines, investigating the illuminations behind the deferral is one of the essentials of keeping the expense inside spending plan and of good headway time execution[23]. The fundamental target of this paper is to perceive the central portions in charge of postponements in the Hong Kong construction industry and pick their relative centrality as seen by various part get-togethers. A study considers, in light of 83 starting late apparent yield factors, gathered into eight principle issue classes, was driven in mid-1995. Reactions from 78 improvement staff from customer, ace and ephemeral master affiliations endorse a solid similarity in insight among customers and guides, for instance concerning the immensity of the poor site the overseers and supervision defer factor and the contractor-related yield factor gathering.[23]

In any case, there was a huge inconsistency among specialists and legally binding labourers, similarly as among clients and impermanent specialists, concerning the rankings of both the individual factors and the factor classes. Suggestions can be given for logically feasible endeavour the officials subject to the discernment. Also, give a foundation to moreover ask about the progression of an envisioned construction duration desire model for adjacent structure adventures. .[23]

The Indian advancement industry is a fundamental bit of the economy of the country and its advancement and a course for a significant bit of India's improvement adventure. The business assumes a crucial job in building up the nation 's framework, a pre-imperative for large amounts of monetary development. Most improvement adventures experience cost overpowers, and it put the immense budgetary related load on the client or owner[24], this exploration was completed to distinguish the makes driving cost to invade in development ventures.. Work area think about alongside poll study was utilized to recognize the reasons for cost overwhelm. A sum of 30 filled surveys were gathered from customers, specialists and temporary workers. The respondents were approached to rate the recorded causes dependent on the likelihood of event and seriousness of effect. Significance of each reason was determined dependent on the aggregate impact of event and effect. For assessment, spearman rank request connection investigation was utilized From the examination of the results, it was identified that understanding exists between respondents on the explanations behind expense attack. The results showed that, moderate essential authority, poor timetable organization, increase in material/machine costs, poor contract the administrators, poor arrangement/delay in giving structure, change in view of wrong work, issues in land acquirement, wrong estimation/estimation technique, and broad stretch among plan and time of offering/offers are the genuine explanations behind expense overpower. The critical causes as recognized by this examination were differentiated and the disclosures from various countries, and there were appropriate resemblances.[24]

Controlling time and cost assault of progress undertakings is colossal in accomplishing amazing fruition of any undertakings. Extraordinarily, headway industry today is facing a crucial threat in accomplishing summit of errand inside evaluated time and cost. This peril is acknowledged by different parts. Wanting to treat this issue, this examination demonstrates a structure for an online pro and choice truly enduring framework to survey the risk estimation of causative fragments of time and cost assault on undertaking accomplishment all through the lifecycle of the progress process. It will be united with undertaking logbook to survey the aftereffects of these variables and figure the loss of time and cost if the risk factors are not controlled. This will achieve by installing the methodology of the neural framework. The program will, in like way, propose the healing activities to control the apparent risk factors. At long last, interesting reports can be conveyed in seeming related issues of the variables and their general effect of errand execution. [20]

Delay can be described as time overpower or enlargement of time to complete the endeavour. Improvement delay is something that can't keep up a key separation from especially in government workplaces in Malaysia. Along these lines, the deferral is a situation when the certifiable headway of an advancement adventure is slower than the organized arrangement or late realization of the endeavours. The explanations behind deferral are taken from the pass composing overview. There is two standard kinds of deferral: tolerable delay and non-justifiable deferral. The composition reviews are sketched out, and the defer framework is created subject to the composition overview rundown in the setting of the open higher learning association.[21]

The development business has a reputation for passing on endeavour over the spending plan. This examination perceives genuine endeavour models speaking to the issue of expense attacks. Eventual outcomes of a survey audit present impression of the essential reasons why building improvement broadens every so often outperform the hidden

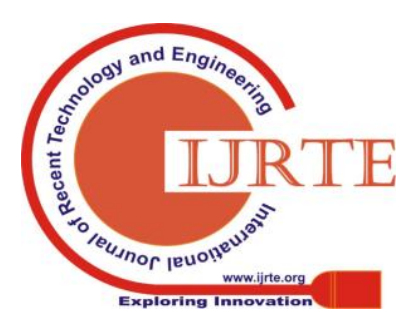


spending check[22]. The paper overviews how the advancement business is responding to the trial of exact arranging. In the space of the workplace, capital cost spending plans and risk the officials; two key closures are made. At first, that complete arrangement information prompts continuously exact spending measures. Additionally, client-driven structure change is the most genuine risk. Clients are the key drivers of advancement, and they ought to thus examine themselves before denouncing the business for being inefficient [22]

\section{E. COST OVERRUN}

Startling expenses brought about more than planned sums associated with cost invade, otherwise called a cost increment or spending overwhelm, because of many like reasons like an underestimation of the genuine expense amid planning, acceleration, unanticipated conditions and the failure of the site supervisory crew to control the financial limit.

\section{F. RISKS IN CONSTRUCTION}

Construction industry generally has an enamorous of risk some of the common risks in construction contracts[18]

They are:

$$
\begin{aligned}
& >\text { Disputes and delay } \\
& >\text { Supervision and direction } \\
& >\text { Damages and injuries } \\
& >\text { Additional factors } \\
& >\text { Cash flow } \\
& >\text { Disputes and arbitration } \\
& >\text { Manual work }
\end{aligned}
$$

\section{G. REASONS FOR COST OVERRUNS IN PROJECT MANAGEMENT}

The central components of the task the board is to guess and track costs to sidestep cost overpowers. While poor execution of endeavor the board assignments can provoke extended costs, you can interface progressively inconspicuous inspirations to the techniques of the errand the board and the central thought of complex exercises. Powerful undertaking administration recognizes such conceivable wellsprings of cost invades early and mitigates their impact.

\section{Methodology}

The procedure for the present venture is to create polls considering every one of the credits identified with expense and time overwhelms of the development ventures, to lead the review among every one of the partners of various activities. This strategy acquires recognizing the risk seriousness factors impacting time overwhelms and cost invades in development ventures [7]. To distinguish time invades and cost overwhelms factors, writing audits, books, gathering and talk with experts associated with the development industry(Site Engineers, Contractors, proprietors, Labors ) were completed in both high spending plan and low spending undertaking. In this investigation, the Questionnaire review was created dependent on ten components of time overwhelms and cost invades [2].

\section{QUESTIONNAIRE STRUCTURE}

The questionnaire survey is based on the likert scale rating . The survey contemplate is classified into two segments. The underlying category includes information like sort of association, estimation of their undertaking, etc and the second part contain the improvement danger factors for evaluation. Risk factors for this investigation are arranged into 10 classes in particular,

$\begin{array}{ll}\text { 1. } & \text { owner related } \\ \text { 2. } & \text { Contractor-related } \\ \text { 3. } & \text { planning and control related } \\ \text { 4. } & \text { technical team related } \\ \text { 5. } & \text { Material related } \\ \text { 6. } & \text { workman-related } \\ \text { 7. } & \text { machineries-related } \\ \text { 8. } & \text { Contract-related } \\ \text { 9. } & \text { climatic conditions } \\ \text { 10. } & \text { Economic-related }\end{array}$

The survey was led dependent on the suspicions, which classify the low and high spending ventures. It is viewed that the greatest estimation of the agreement ought to be Rs5 Crore for the low spending undertaking above, which will be considered as a high spending venture for our investigation. The subtleties of surveys and the task subtleties are below

\section{SPSS}

Measurements is a product bundle utilised for factual examination. SPSS is a generally utilised program for factual investigation in sociology. It is likewise utilized by economic scientists, wellbeing analysts, review organisations, government, instruction specialists, promoting associations, information diggers, and others. Notwithstanding measurable examination, information the executives (case determination, record reshaping, making inferred information) and information documentation (a metadata word reference was put away in the information record) are highlights of the base programming.

SPSS Statistics involves limitations on inside document structure, information types, information preparing, and coordinating records, which extensively improve programming techniques. SPSS have a $2 \mathrm{D}$ table format, where the lines ordinarily speak to cases, (for example, people or family units) and the sections speak to estimations, (for example, age, sex, or family salary). All information handling happens successively case-by-case through the document. Bigger datasets, for example, factual reviews are all the more regularly made in information section programming, or entered amid PC helped individual meeting, by examining and utilising optical character acknowledgement and optical imprint acknowledgement programming, or by catch in online surveys. These data formats are perused into SPSS.

\section{ANALYSIS OF DATA}

The goal of investigating this area is to set up the variables under the gatherings of causes recognized from the writing survey and the positioning as per their noteworthy impact towards development gear the board. This investigation 
utilized for recognizing the main considerations that influence the development of gear and improved proficiency of the development venture.

Table I : Response rate

\begin{tabular}{|c|c|c|c|c|}
\hline S.No & $\begin{array}{l}\text { Demogr } \\
\text { aphic } \\
\text { Profile }\end{array}$ & $\begin{array}{c}\text { Category } \\
\text { (Years) }\end{array}$ & $\begin{array}{c}\text { No. of } \\
\text { Respondent }\end{array}$ & Percentage \\
\hline \multirow{4}{*}{1} & \multirow{4}{*}{ Age } & $\geq 29$ & 10 & 6.89 \\
\hline & & 30 to 39 & 17 & 13.20 \\
\hline & & 40 to 49 & 81 & 56.65 \\
\hline & & Above 50 & 35 & 23.07 \\
\hline \multirow{4}{*}{2} & \multirow{4}{*}{$\begin{array}{l}\text { Experien } \\
\text { ce in the } \\
\text { construc } \\
\text { tion field }\end{array}$} & $\begin{array}{l}\text { Less than } \\
2 \text { years }\end{array}$ & 15 & 10.49 \\
\hline & & $2-5$ years & 9 & 6.29 \\
\hline & & 6 to 10 & 65 & 45 \\
\hline & & $>15$ & 33 & 24.1 \\
\hline \multirow{3}{*}{3} & \multirow{3}{*}{$\begin{array}{c}\text { Job } \\
\text { category }\end{array}$} & Contractor & 25 & 17.78 \\
\hline & & Engineer & 90 & 64.33 \\
\hline & & Client & 27 & 18.88 \\
\hline \multirow{4}{*}{4} & \multirow{4}{*}{$\begin{array}{l}\text { Type of } \\
\text { projects } \\
\text { undertaken }\end{array}$} & $\begin{array}{c}\text { Housing } \\
\text { Construction }\end{array}$ & 84 & 59.44 \\
\hline & & $\begin{array}{l}\text { Public } \\
\text { Project }\end{array}$ & 21 & 14.68 \\
\hline & & $\begin{array}{c}\text { Industrial } \\
\text { Construction }\end{array}$ & 33 & 22.37 \\
\hline & & Others & 5 & 3.49 \\
\hline
\end{tabular}

Table II : Low budget project Rank

\begin{tabular}{|l|c|}
\hline \multicolumn{1}{|c|}{ Delay factor categories } & Rank \\
\hline Workmen related [1] & 1 \\
\hline Project planning and control related & 2 \\
\hline Economic related & 3 \\
\hline climatic conditions & 4 \\
\hline Contractor related & 5 \\
\hline Owner related[3] & 6 \\
\hline Contract related & 7 \\
\hline Machinery-related & 8 \\
\hline Technical Team related[7] & 9 \\
\hline Material related & 10 \\
\hline
\end{tabular}

Table III :High budget project rank

\begin{tabular}{|l|c|}
\hline \multicolumn{1}{|c|}{ Delay factor categories } & Rank \\
\hline Material related & 1 \\
\hline Technical Team related & 2 \\
\hline Economic related & 3 \\
\hline Contractor-related & 4 \\
\hline Project planning and control related & 5 \\
\hline Contract related & 6 \\
\hline Workmen related & 7 \\
\hline climatic conditions & 8 \\
\hline Owner related & 9 \\
\hline Machinery-related & 10 \\
\hline
\end{tabular}

\section{RESULTS AND DISCUSSION}

All the questionnaire review have been disseminated and gathered from the undertaking chief of the task or designer at the site or different contractual workers, customers and specialists. At times, the advisor addressed the conduct of their customers, both from the proprietor and the contractual worker side. Polls were conveyed and gathered from different organizations as follows,

- Owner

- Contractors

- Clients

- Consultants

- Engineers

- Project Manager

- Workers

\section{CONCLUSION}

Proficient and viable administration of a venture is the key quality towards fruitful, auspicious and beneficial fulfillment of the task. Arranging, checking, controlling expense and Quality are the real parts of undertaking the executives and insightful utilisation of these apparatuses gives a forefront to the implementation of projects- whether of comparable sort or unique. In this investigation, it was comprehended that the risk seriousness fluctuated in low and high spending development ventures. In low spending development extends, the topmost risk is labour accessibility/utility, and for the large spending venture, top risk inferable from material preparation. For the most part, in low spending undertakings, there won't be a venture control group to screen the assets need for the task. From the idea to appointing of the undertaking, it is the individual obligation of the site specialist to send the needed assets. The prime focal point of the specialist is to convey the venture on time inside the distributed spending, which may not be conceivable because of flighty conditions experienced amid the implementation of the task. It was distinguished from our investigation that the topmost factor which influences the lower spending venture, is fundamentally workers/work-related. It was comprehended from our examination that the absence of sufficient labour powers the site supervisory group to send the accessible labour at the territory which can't deliver the required outcomes.

Consequently, it results in cost and time invade of the venture in the greater part of the tasks which one should be dispensed with. In the present situation, it isn't anything but difficult to get gifted labour in the ideal area. In this theory, we recommend the small scale organisations to get the talented labour from any of the preparation foundations which have just been taken up by the greater part in the development business. It might have a few recognitions that we have to pay more to the talented labour however considering the profitability of the workers; it will generally yield excellent outcomes in the auspicious finishing of the undertaking inside the acknowledged/assigned expense.

In higher spending ventures, we found that the association sends separate groups for arranging, bookkeeping, acquiring and other adjusting works. In any case, it was discovered that a few elements directly affect the fruitful finishing of the venture because of the absence of influence on specific variables. In this investigation, it discovered that the highest risk factor inferable from time and cost invade of the undertaking is material administration. Treatment of materials at site and convenient

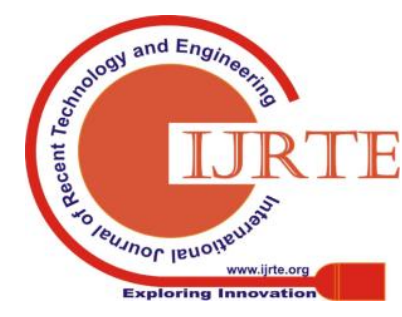


preparation of materials assume a fundamental job in the fruitful finishing of the undertaking. The present market costs of the mass materials and heightening costs for the all-out venture length to be anticipated and materials obtained depends on the task necessity. If the stock was kept up appropriately and legitimate stock administration will have a decent outcome as far as convenient fruition of the undertaking which for the most part, drive the expense of the venture.

\section{REFERENCES}

1. Aibinu A.A and G.O. Jagboro, "The effects of construction delays on project delivery in Nigerian construction industry" International Journal of Project Management ' Vol. 20, No. 8, pp. 593- 599(2002)

2. Akinci, Burcu. \& Fischer, Martin, "Factors Affecting Contractors' Risk Of Cost Overburden", Journal of Management in Engineering, Vol. 14, No.1,67-76. (1998)

3. Ali,A.S.,Kamaruzzaman,S.N , "Cost Performance for Building Construction Projects in Klang Valley", Journal of Building Performance, Vol. 1, No. 1,110-110. .(2010)

4. Arvan, L. and Leite, "Cost Overruns in Long-Term Project", International Journal of Industrial Organization, 8(3),443-67(1990).

5. Assaf, S. A., \& Al-Hejji, S, "Causes of delay in large construction projects", International Journal of Project Management $\mathrm{Vo}$ 24(4),349-357(2006)

6. Battaineh, A.M.O.a. H.T, "Causes of construction delay traditional contracts", International Journal of Project Management Vol (20): 67 -73(2002)

7. Chan Albert P.C,"Time cost relationship of public sector projectsin Malaysia", International Journal of project Management Vol. 19 No.4, pp.223-229(2001).

8. Chan, D.W.M., \&Kumaraswamy, M.M , "A study of the factors affecting construction durations in Hong Kong", Construction Management and Economics, 13(4),319-333(1995).

9. Kaming P.F, P.O. Olomolaiye, G.D. Holt and F.C Harris, "Factors influencing construction time and cost overruns on high-rise projects in Indonesia", Journal of Construction Management and Economics. Vol. 15, No.1, pp.:83-94. (1997)

10. OdehAbdalla.O and T. BattainehHussie,"Causes of construction-delay:traditional contracts", International journal of Project Management Vol. 20, No.1, pp.67-73. (2002)

11. M. Sambasivan, Y. Soon, "Causes and effects of delays in Malaysian construction industry", International Journal of Project Management 25517-526. ( 2007)

12. M.W. Alaghbari, A. Razali Khadir, Salim Azizahand Ernawati , "The significant factors are causing delay of building construction projects in Malaysial", Journal of Engineering, construction and Architectural Management, Vol.14,No.2, No. 8, PP.192-206. (2007)

13. R. Arditi, G. Akan, S. Gurdamar, "Reasons for delays in public projects in Turkey", Construction Management and Economics 3 171- 181. (1985)

14. R.F Aziz, "Ranking of delay factors in construction projects after the Egyptian revolution",Alexandria Engineering Journal(2013)

15. F. Fugar, A. Agyakwah-Baah, "Delays in building construction projects in Ghana" Australasian", Journal of Construction Economics and Building 10 (1/2)103-116. (2010)

16. N. Mansfield, O. Ugwu, T. Doran, "Delay causes and cost overruns in Nigerian construction projects" International Journal of Project Management 12 (4)254-260. (1994)

17. S. Assaf, M. Al-Khalil, M. A-Hazmi, "Delay causes in large building construction projects" Journal of Management in Engineering, ASCE 11 (2)45-50(1995)

18. S. Shanmugapriya1, Dr K. Subramanian, "Investigation of Significant Factors Influencing Time and Cost Overruns in Indian Construction Projects", International Journal of Emerging Technology and Advanced Engineering Volume 3, Issue 10,October2013)

19. Aftab Hameed Memona, "Web-based Risk Assessment Technique for Time and Cost Overrun". Journal of Emerging Technology and Advanced Engineering (Sep2013)
20. Hamzah, M.A. Khoury, I. Arshad, "Cause of Construction DelayTheoretical framework", Journal of Management in Engineering (2006)

21. Chan Daniel and M. Kumaraswamy, "An evaluation of construction time performance in the building industry", Journal of Building and Environmental (1996)

22. Subramanian, PS Sruthi, "Causes of Cost Overrun in Construction", Journal of Building and Environmental (June2014)

23. Wonkyoung Seo and Youngcheol Kang, "Performance Indicators for the Claim Management Process of Construction Projects" Journal of construction engineering and management ASCE January 2019

24. Dhaval Parikh, G. J. Joshi and D. A. Patel, "Development of Prediction Models for Claim Cause Analyses in Highway Projects", Journal of Legal affairs and Dispute Resolution in Engineering and Construction Volume 11 Issue 4- Nov 2018

25. Tak Wing Yiu, Tingting Liu and Lai Chun Kwok, "Explicating the Role of Relationship in Construction Claim Negotiations", Journal of Construction Engineering and Management Volume 144 Issue 2 February 2018

\section{AUTHORS PROFILE}

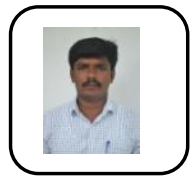

Mukilan K Completed his Master of Engineering in the field of Construction Engineering and Management in RVS Technical Campus, Coimbatore in the year of 2015 .He completed his Bachelor of Technology under Kalasalingam University in the year of 2012. He has more than five years of experience in teaching. He has published various papers in the reputed journals. His main thrust research areas are Construction management

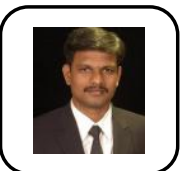

Ramesh Babu C completed his Ph.D. from IIT Chennai. He has more than ten years of experience in teaching and research. His areas of research includes pervious concrete, geo polymer concrete, and high volume fly ash concrete 